\title{
A DIGITALIZÁCIÓ MINT A KISKERESKEDELMI TEVÉKENYSÉGET INTEGRÁLÓ TÉNYEZŐ
}

A cikk célja annak bemutatása, hogy a digitális technológiák hogyan alakítják át és integrálják kiskereskedelmi tevékenység különböző területeit. Nemzetközi szakirodalom és szekunder információk alapján a szerző megvizsgálta, hogy a digitális megoldások hogyan integrálják az online és offline csatornákat, a kiskereskedelmi és fogyasztói szerepeket, illetve a termékeket és szolgáltatásokat. A kiskereskedő és a fogyasztó által használt digitális eszközök összekapcsolódása új, tágabb értékesítési környezetet hoz létre, amely átlépi a kiskereskedő online és offline csatornáinak határait. Az önkiszolgáló és virtuális technológiák egyre több lehetőséget kínálnak a fogyasztói részvétel növelésére és az eladószemélyzet feladatainak kiváltására. Végül pedig a kiskereskedelemben a hangsúly a termékalapú értékesítésről a kiskereskedelmi szolgáltatások felé tolódik el, a problémamegoldás, tanácsadás kerül előtérbe online technológiák és virtuális valóságra épülő megoldások alapján.

Kulcsszavak: digitalizáció, kiskereskedelem, értékesítés

A kiskereskedelmi szektort számos tényező, így például a nemzetközi terjeszkedés kihívásai, a gazdasági folyamatok és a technológiai fejlődés folyamatosan formálja. A technológiai változások egyik legföbb hajtóereje a digitalizáció. A Deloitte (2016) kutatása alapján a digitális interakciók a bolti költések több mint felére (56\%) hatással vannak, miközben a kiskereskedelmi forgalom 90 százaléka fizikai kiskereskedelmi egységekben zajlik világszerte (eMarketer, 2016). Ennek következtében a kiskereskedelmi vállalatok azzal szembesülnek, hogy a fogyasztók nem az egyes csatornákhoz ragaszkodnak, hanem ahhoz, hogy a vásárlási folyamat során konzisztens ajánlattal, árakkal és kommunikációval találkozzanak minden csatornában, illetve zökkenőmentes legyen a csatornák közötti váltás (Deloitte, 2018).

A kiskereskedelmi szakirodalom az utóbbi években intenzíven foglalkozott a digitalizáció szerepével és hatásaival. A kutatók számos, kiskereskedők által alkalmazott, digitális megoldást tanulmányoztak az évek során. Így például vizsgálták a digitális, interaktív display fogyasztókra gyakorolt hatásait (Grewal et al., 2011; Pantano, 2014), a mobilapplikációk vásárlási döntési folyamatban betöltött szerepét (Pantano, 2014; Shankar et al., 2011; Pantano - Viassone, 2014; Inman - Nikolova, 2017), az önkiszolgáló technológiákat (Pantano, 2004; Inman - Nikolova, 2017), digitális megoldással támogatott árazást és akciókat (Grewal et al., 2011; Shankar et al., 2011, Inman -Nikolova, 2017), illetve az okostükör (GREWAL et al., 2011) alkalmazási lehetőségeit.

A legfrissebb publikációk a digitális megoldások strukturálására törekednek. Hagberg et al. (2016) a kiskereskedelemben alkalmazott digitális megoldásokat rendszerezte piaci szereplők, áru- és információ-áramlás, kiskereskedelem kontextusa és kiskereskedelmi ajánlatok alapján. Willems et al. (2017) pedig az eladótérben használt digitális technológiákat osztályozta a fogyasztói szükségletek, illetve a vásárlási döntési folyamat szakaszai alapján. A kiskereskedelmi digitális technológiákat áttekintő cikkek (Hagberg et al., 2017, Willems et al., 2017) egyik leg- fontosabb következtetése, hogy a digitalizáció elmossa a határokat az offline és online csatornák, a kereskedő és a fogyasztó, illetve a termékek és szolgáltatások között. Az eddigi szakirodalom viszont kevésbé koncentrált a digitális technológiák határvonalakat átlépő, integráló szerepére.

A cikk célja annak bemutatása, hogy a kiskereskedelemben alkalmazott digitális technológiák hogyan integrálják a kiskereskedők tevékenységét: az értékesítési és kommunikációs csatornákat, termékeket és szolgáltatásokat, valamint a kereskedői és fogyasztói szerepeket. A kutatási kérdés megválaszolásához nemzetközi kiskereskedelmi vállalatok körében szekunder adatokat gyüjtöttem, amelyek segítségével illusztrálom a kiskereskedelmi digitális megoldások integráló szerepét.

A tanulmány a szakirodalom áttekintésével kezdődik különös tekintettel a digitalizáció fogalmára, kiskereskedelmi vonatkozásaira. Ezután kerül sor a kiskereskedelemben alkalmazott, digitális megoldások integráló szerepének tárgyalására, amelyet nemzetközi vállalatok példái szemléltetnek. Az összegzésben foglalom össze a legfontosabb következtetéseket, valamint a kutatás korlátait és a jövőbeni kutatási lehetőségeket.

\section{Szakirodalmi áttekintés}

A digitális technológiák használata ma már mindennapos mind a vállalatok, mind a fogyasztók részéröl. A digitalizáció tulajdonképpen az analóg formában megjelenített objektumok (szám, kép, szöveg, film) digitális formában (bináris kódok) való megjelenítését, illetve elektronikus adatfeldolgozását foglalja magában (Meriam-Webster szótár). A Gartner Research (2018) megfogalmazásában a digitális technológiák alkalmazása megváltoztatja az üzleti modellt, amelynek révén a vállalat számára új bevételnövelö, értékteremtő lehetőségek nyílnak meg.

A digitalizáció nem új jelenség a kiskereskedelemben sem, mivel a vonalkódok alkalmazásával lehetővé vált számos kiskereskedelmi (beszerzési, logisztikai és értékesítési) folyamat digitalizálása. Az Internet és a mo- 
biltelefonok térhódításával azonban a fogyasztók is aktív alakítóivá váltak a digitalizációnak. Ennek következtében a korábban, egymástól függetlenül müködő, kiskereskedő és fogyasztó által irányított digitális folyamatok összekapcsolhatóvá váltak és új alkalmazási területek nyíltak meg a kiskereskedelmi szektorban (Hagberg et al., 2016).

Az elektronikus kiskereskedelem sokáig a digitalizáció kiemelt kutatási területének számított, azonban ma a digitális megoldások már jóval túlmutatnak az online kereskedelmen és megjelentek a kiskereskedelmi üzletekben (Pauwels et al., 2011). A fogyasztók ugyanis az üzletben is használnak mobilapplikációkat az árak összehasonlítására, terméktulajdonságok felderítésére, bevásárló lista létrehozására, illetve fizetés kezdeményezésére (Ström et al., 2014; Groß, 2015; Pantano - Priporas, 2016). Ezenkívül a tárgyak Internete, a kiterjesztett és virtuális valóságra, mesterséges intelligenciára épülő megoldások, a big data-alapú marketing- és értékesítési tevékenység számtalan lehetőséget rejtenek magukban a digitális megoldások kiskereskedelmi alkalmazásában (Grewal et al., 2017).

A kiskereskedelmi vállalatok korábban ár, választék és szolgáltatások mentén versenyeztek egymással, most viszont az információtechnológia hozza létre a fogyasztói értékteremtésen alapuló versenyelőnyt (Hänninen et al., 2017). Willems és szerzőtársai (2017) a fogyasztói értékteremtésnek több módját azonosították. A digitális megoldások csökkenthetik a vásárlási döntési folyamathoz kapcsolódó, fogyasztói erőfeszítéseket, növelhetik a fogyasztó által érzett hasznosságot, illetve hedonikus élményeket képesek létrehozni a fogyasztás során.

Lehdonvirta (2012) a digitális fogyasztás három szakaszát különítette el: az online vásárlást, a részt vevő és a virtuális fogyasztást. Az online vásárlási szakaszban a fogyasztók a fizikai üzletekben való vásárlást részben digitális és kiterjesztett valóságon alapuló fogyasztással helyettesíthetik. Ennek következtében a digitalizáció a fogyasztás időbeli és földrajzi dimenzióit, illetve a termékek közötti választást kiterjeszti. A részt vevő fogyasztás során az új információmegosztási és együttműködési lehetőségek a fogyasztót magát is formálják. A digitális megoldások a fogyasztóknak új szerepet kínálnak, a státusuk átalakul, passzív fogyasztóból aktív résztvevővé vagy termelö-fogyasztóvá válnak (Ritzer - Jurgenson, 2010). A virtuális fogyasztás során új virtuális javak is megjelennek az árukínálatban, amelyeknek a fogyasztása azonban sok hasonlóságot mutat a tárgyi javakkal. Így például a virtuális javak is képesek társadalmi különbségeket kommunikálni, kapcsolatokat építeni, problémát megoldani, sőt fogyasztói élményt növelö, hedonikus funkciót is elláthatnak a fogyasztó életében. A virtuális és tárgyi javak azonban egy dologban mindenképp különböznek, nem képesek élettani szükségleteket kielégíteni (Lehdonvirta, 2012).

A digitalizáció hatására átalakult fogyasztói magatartás természetesen nem hagyja változás nélkül a kiskereskedelmi vállalatok tevékenységét sem. Hagberg és szerzőtársai (2016) megállapítása szerint a digitális fejlődés hatással van az áru- és információcserére, a kiskereskedelmi ajánlatra, az értékesítés kontextusára, valamint a kiskereskedelmi tevékenység szereplőire.
- A kiskereskedők és fogyasztók által használt digitális eszközök új kommunikációs csatornákat, disztribúciós formákat és tranzakciókat hívtak életre. A digitalizáció egyik fontos előnye, hogy a kiskereskedők közvetlenül kapcsolatba tudnak lépni a vásárlóikkal és személyre szabott kommunikációt valósíthatnak meg. Ezenkívül a cég nyomon tudja követni a fogyasztók közötti kommunikációt, továbbá számolniuk kell azzal, hogy harmadik fél is bekapcsolódik a vállalat a fogyasztók közötti információáramlásba (Zhou - Duan, 2015). Ilyen harmadik fél lehet pl. a termékek és árak összehasonlításával foglalkozó platformok.

Az online csatornák bekapcsolásával új disztribúciós formák is létrejöttek, amelyek alapvetően az áruhoz való hozzáférést segítik elő. Ilyen disztribúciós formát jelentenek a különböző felvevőpontok (csomagmegőrzők, kizárólag áruátvételt biztosító üzletek), vagy a rendelést segítő felületek (QR-kóddal leolvasható termékek köztéri plakátokon). A tranzakciók területén az egyik leggyorsabban fejlődő terület a készpénznélküli fizetési módok bővülése, amelynek során a készpénzes fizetést egyre inkább kiváltják a bankkártyás, érintésnélküli, illetve a mobiltelefonos fizetések (Taylor, 2016).

- A kiskereskedelmi ajánlat az áruválasztékban ragadható meg leginkább. A digitalizáció lehetővé teszi az áruválaszték bővítését anélkül, hogy a fizikai kiskereskedelmi kapacitást jelentősen növelni kelljen (Anderson, 2006). Az online felületeken ugyanis jóval nagyobb kínálatot lehet bemutatni, mint az üzletekben. A digitális megoldások ezenfelül az árubemutatást is segíthetik, például elektronikus feliratok, vagy az üzletben elhelyezett, interaktív információs táblák segítségével. A digitális fejlődés számos eszközt kínál a kiskereskedelmi vállalatok számára, hogy újabb, fogyasztói élményt növelő szolgáltatásokat nyújtsanak a vásárlóknak (Renko - Druzijanic, 2014). Az új kiskereskedelmi technológiák révén innovatív ár- és promóciós megoldásokat alkalmazhatnak a kiskereskedők (Grewal et al., 2011). Így például számos kiskereskedő vezetett be dinamikus árazást, amely akár a fogyasztók szintjén képes árdiszkriminációt megvalósítani. A fogyasztói szintủ árdiszkrimináció leggyakrabban egyedi árengedmények nyújtásával oldható meg olyan eszközökkel, mint pl. a rádiófrekvenciás azonosító, wifi-hálózat, GPS, bluetooth vagy beacon. A promóciók (pl. árengedmények, kuponok) terén szintén egyre jellemzőbb a személyre szabott ajánlat (Barone - Roy 2010).

- A digitalizáció hatással van az értékesítés kontextusára is. Bár az online csatornák a vásárlások egy részét elhódították a hagyományos üzletektől, azonban az Internet sok esetben erősítette a fizikai üzletek szerepét (Fuentes et al., 2017; Hultman et al., 2017). Olyan technológiák alkalmazásával, mint a digitális információs táblák, okos bevásárlókocsik, érzékszervi marketingeszközök a hagyományos üzletek jelentős mértékben tudják az üzletben a fogyasztói élményt növelni (Pantano - Viassone, 
2015). Ezenkívül a vásárlás új helyszínekre (pl. saját otthon, közlekedési eszköz) tevődik át az okostelefonok elterjedésének köszönhetően.

- A digitalizáció megváltoztatja a kiskereskedelmi környezet szereplői közötti kapcsolatot. A digitális technológiák használata révén a fogyasztó és a kiskereskedő közötti információs aszimmetria csökken. Elöfordulhat, hogy a vásárlók sokkal jobban tájékozottak a piaci kínálatról, mint az eladószemélyzet (Doherty - Ellis-Chadwick, 2010). A kiskereskedők viszont a vásárlókról rendelkeznek minden eddiginél több információval. A gyorsan halmozódó, sokféle vásárlói adat (numerikus, szöveges, kép) utat nyit a big data és adatbányászati alkalmazások felé. Ebben a kontextusban azonban a fogyasztók már kevésbé érzelmekkel, attitűdökkel rendelkező egyénekként, hanem adatokként jelennek meg, amelyet Cluley és Brown (2015) dividualizáció jelenségének nevezett. A dividualizáció olyan eszközök alkalmazásához vezet, amely az emberek, adatok és dolgok új kombinációját alakítják ki (Cluley - Brown, 2015). Ritzer (2001) szerint ez a folyamat a kiskereskedelmi tevékenység dehumanizációjához vezet, mivel az emberi interakcióból fakadó elégedettség érzetét nehéz kialakítani online környezetben.

A kiskereskedelmi környezetben a digitalizáció térhódításával megjelentek továbbá olyan piaci szereplők, amelyek részben vagy egészben közvetetté teszik a kiskereskedő és a vásárló közötti kapcsolatot. A többszereplős platformok, mint az Amazon.com, eBay a kiskereskedők és fogyasztók piacát teremtik meg és közvetítenek közöttük (Hänninen et al., 2017).

\section{A kiskereskedelmi digitális megoldások integrációs szerepe}

Hagberg et al. (2016) megállapítja, hogy a digitalizáció növeli a kiskereskedelemben a hibrid jelenségeket, ennek következtében az online-offline, digitális-analóg, illetve a materiális és virtuális jellemzők egyre nehezebben választhatók szét (Denegri-Knott - Molesworth, 2010). A digitalizáció elmossa a határokat az offline és online csatornák (Verhoef et al., 2016), a kereskedői és a fogyasztói szerepek (Keeling et al., 2013), illetve a termékek és szolgáltatások között (Hagberg et al., 2017).

A digitalizáció integráló hatását a kiskereskedelmi szakirodalom alapján és nemzetközi kiskereskedelmi vállalatok példáján keresztül mutatom be. A kiskereskedők által alkalmazott digitális megoldásokat szekunder kutatással gyüjtöttem össze az üzleti sajtó, a vállalatok kommunikációs híreit felhasználva.

\section{Online és offline csatornák integrációja}

A digitális eszközök új kiskereskedelmi környezetet hoznak létre, amelynek egyaránt része az online, a mobil csatorna és a kiskereskedelmi üzlet is. Verhoef és szerzőtársaik (2007) megállapítják, hogy offline és online üzletek különböző ajánlatot és vonzerőt képviselnek a fogyasztók számára, amelyek integrálásával a kiskereskedő növelheti a fogyasztói élményt. A csatornák integrációjának az igazi hajtóereje azonban az, hogy a fogyasztók egyetlen vásárlási döntési folyamaton belül több csatornát kombinálnak. Ennek következtében a fizikai és a digitális csatornák összeolvadnak a vásárlási folyamat során (Hagberg et al., 2016), amelyet omnichannel vagy integrált kiskereskedelemnek neveznek (Blitz, 2016). A következőkben bemutatom, hogy az egyes (üzlet, online és mobil) csatornákban megjelenő digitális megoldások, hogyan integrálják a többi csatornát.

A fizikai üzlet az omnichannel értékesítés egyik fontos pillére (e.g. Brynjolfsson et al., 2013; Verhoef et al., 2015; Blom et al., 2017; Huré et al., 2017). Az üzletekben a digitális eszközök elsősorban a termékekkel kapcsolatos információkeresést (interaktív terminálok, digitális kirakat vagy az okos tükör), az eladótérben való tájékozódást (intelligens bevásárló kocsi, rádiófrekvenciás azonosító, bluetooth és beacon), illetve fizetést segítik (Pantano - Viassone, 2015; Verhoef et al., 2015).

A Nike Fuel Station üzlete számos technológiát alkalmaz annak érdekében, hogy az offline és online környezetet integrálja és az üzletet élményközponttá alakítsa a vásárlók számára. A vásárló először egy interaktív LEDfallal találkozik, amely a vásárló mozgását visszatükrözi, majd egy mozgásérzékelővel ellátott LCD-falon megjelenik az előző mozgás, amely életnagyságban ábrázolja a vásárlót és válaszol a mozgásra. A filmet akár a fogyasztó meg is oszthatja közösségi oldalakon. Az eladószemélyzet kiterjesztett valóság technológia segítségével tudja bemutatni a kiválasztott terméket. Az üzletben található okostükröt megközelítve egy digitális manöken jelenik meg és az üzletben található termékeket mutatja be. Az üzletben továbbá interaktív érintőképernyős megoldásokat alkalmaznak árubemutatásra, a Nike futóklub eseményeinek ismertetésére, vagy akár arra is lehetőséget biztosít, hogy a terméket a weboldalon keresztül szerezze be a vásárló (Retail Design Blog, 2012).

A fizikai üzletekben alkalmazott digitális megoldások a vásárlók számára értéket teremtenek a vásárláshoz kapcsolódó funkcionális és hedonikus élmény növelése révén (Huré et al., 2017). Az üzletben megjelenő digitális alkalmazások továbbá képesek erősíteni a fizikai csatorna szerepét. Ugyanis az üzlet gyakoribb felkeresése révén a fogyasztó személyes kapcsolatot tud kialakítani a kiskereskedővel, ami növeli a vásárló elégedettséget és lojalitását (Hernant - Rosengren, 2017). Nem véletlen, hogy számos online kiskereskedö is fizikai üzlethálózatot is nyitott, amelynek köszönhetően az offline csatorna által nyújtott előnyökből is profitálhat.

Az online csatorna sok esetben fonódik össze a fizikai csatornával click-and-collect, illetve click-and-drive formában (Hagberg et al., 2016). Ebben az esetben a vásárlási döntési folyamat jelentős része online zajlik és a fizikai csatornákban kizárólag a tranzakciót és az áruátvételt bonyolítják le. A Tesco például olyan üzleteket alakított ki, amelyekben nem lehet vásárolni, csak árut átvenni és fizetni. Az online értékesítés terjedésével további új átvevőpontokat hoztak létre a kiskereskedelmi cégek, amelyek már kilépnek a bolti környezetből és frekventált közlekedési csomópontokban lehet hozzájutni a megrendelt termékekhez (Cullinane, 2009). Számos példát láthatunk az üzleten kívüli átvevő pontok létrehozására a vezető kiskereske- 
delmi cégek körében. Az angol kiskereskedők, mint pl. az angol John Lewis érdekeltségébe tartozó Waitrose szupermarketlánc csomagmegőrzőben (Waitrose, 2014) vagy a versenytárs Sainsbury's a metrómegállók (Sainsbury’s 2016), a holland Ahold pedig repülőtereken található parkolóházak csomagmegőrzőjébe szállítja a megrendelt árut. Ezek a megoldások megspórolják az utolsó kilométerek költségét a kiskereskedőnek, a vásárlónak pedig kényelmes áruátvételi lehetőséget teremtenek. A Tesco és az Auchan még ennél továbblépett, ugyanis interaktív virtuális szupermarketeket hozott létre közlekedési csomópontokban. A Tesco 2011-ben Dél-Koreában a metróállomásokon (Tesco 2012), 2012-ben a gatwicki repülőtéren vezette be virtuális szupermarketjét (Bearne, 2012). A vásárlók egy mobilapplikáció segítségével olvassák le a digitális falról a megvásárolni kívánt termékek vonalkódját, amelyből bevásárló listát készíthet és az elutazás előtt megrendelheti az árukat, amelyeket a Tesco a megadott napon szállítja házhoz.

$\mathrm{Az}$ internetkapcsolattal ellátott mobiltelefon, tablet szintén alkalmas arra, hogy további csatornával összekapcsolódjon. A mobiltelefonoknak ugyanis egyre nagyobb szerepe van az üzletben való vásárláskor. Fuentes és szerzőtársai (2017) a mobiltelefonok szerepét vizsgálták bolti környezetben és megállapították, hogy az okostelefonok elterjedésével az üzlet egy tágabb környezet része lesz. Az üzlet nem csupán kereskedelmi funkciókat tölt be, hanem információs (termékinformációk böngészése, termék helyének megtalálása az üzletben), közösségi (a telefonbeszélgetés az üzletben játszódik és az üzlet csak háttér, visszajelzés, tanács kérése barátoktól, családtagoktól a termékről) térként is müködik. Ezenkívül az okostelefonok nem kereskedelmi helyszíneken (pl. közlekedés során) is lehetővé teszik a vásárlást, amelyek tovább tágítják a kiskereskedelmi értékesítési környezetet (Cullinane, 2009).

Az értékesítési környezetbe továbbá új szereplök is bekapcsolódhatnak többszereplős mobilplatformok révén, amelyek például lehetőséget kínálnak a kiskereskedők választékának és árainak az összehasonlításához. A Shelfbucks (Drug Store News, 2015) vagy a ShopSavy (Digital Commerce, 2012) mobilapplikáció lehetőséget ad arra, hogy a fogyasztó a megvásárolni kívánt termékek vonalkódját beszkennelje és tájékozódjon arról, hogy a termék melyik üzletben, milyen áron érhetö el. Az alkalmazás továbbá vásárlói vélemények és akciók keresésére is alkalmas. A tartózkodási hely megosztásán alapuló applikációk, mint például a FourSquare Swarm mobilapplikációja, amelyen keresztül a felhasználók bejelentkezhetnek és megnézhetik, hogy a közelben tartózkodnak-e barátaik, ismerőseik, akiknek üzenetet küldhetnek és találkozhatnak velük (Savitz - Koester, 2012). Mivel a tipikus találkozási helyszínek kiskereskedelmi üzletek és vendéglátóegységek, ezért ezek a vállalatok tudatosan alakíthatják és ösztönözhetik a felhasználók üzletválasztását.

\section{Kiskereskedelmi és fogyasztói szerepek integrációja}

A digitalizáció interaktív folyamat (Fors, 2010), amely formálja mind a fogyasztók, mind a kiskereskedők maga- tartását, azonban a fogyasztók és kiskereskedők maguk is aktívan alakítják a digitális fejlődés folyamatát (Moisander - Eriksson, 2006).

A kiskereskedő és a fogyasztó által használt digitális eszközök egyre gyakrabban kapcsolódnak egymáshoz (Pantano - Timmermans, 2014; Balaji - Roy, 2017), amelynek révén a kiskereskedelmi vállalatok, az eladószemélyzet és a fogyasztók között újfajta kapcsolatok jönnek létre, és a határvonalak elmosódnak a kiskereskedelmi tevékenység és a fogyasztás között (Ritzer - Jurgenson, 2010). Így például az önkiszolgáló technológiák alkalmazásával a fogyasztó részt vesz a kiskereskedelmi tevékenység előállításában, létrehozásában (Sorescu et al., 2011). Az eladószemélyzetre is hatással van a digitalizáció, mivel a vásárlók gyakran digitális eszközökön tájékozódnak a megvásárolni kívánt termékekről, amely kiváltja az eladószemélyzet értékesítési feladatainak egy részét, illetve megváltozik a feladatkörük (Hagberg et al., 2017).

A kiskereskedelmi vállalatok számos módot találnak arra, hogy a fogyasztókat „,foglalkoztassák”, azaz a kiskereskedelmi tevékenységbe bevonják. A digitalizáció lehetővé teszi, hogy a fogyasztók maguk lássanak el olyan tevékenységet, amely korábban az eladószemélyzet feladata volt. Szinte mindegyik nemzetközi élelmiszer-kiskereskedő ma már alkalmaz önkiszolgáló pénztárgépeket, ahol a készpénzes fizetési módtól, az érintés nélküli bankkártyákon át egészen a mobilfizetésig terjednek a lehetőségek. Az önkiszolgálás másik fontos területévé vált a digitális eszközökön keresztül megvalósuló információnyújtás, tanácsadás. Az amerikai Stop\&Shop üzletlánc például szkennereket biztosít a vásárlók számára, amelynek segítségével a vásárlók maguk tájékozódhatnak az árról és az aktuális promóciókról (Gallagher, 2011). A Sainsbury’s pedig a lojális vásárlóit kérte fel, hogy a termékekről értékelést írjanak a weboldalra, amely információforrásként szolgálhat a többi vásárló számára (McEleny, 2011). A kiskereskedelmi vállalatok szívesen vonják be a fogyasztókat az áruválasztékkal kapcsolatos döntésekbe is. A vásárlók véleményt nyilváníthatnak az áruválaszték kialakításával kapcsolatban, tesztelhetik a kereskedelmi márkákat, vagy új termékre tehetnek javaslatot.

Talán a világ legnagyobb online kiskereskedője, az Amazon tart a legelörébb a bolti önkiszolgáló és automatizált technológiák alkalmazásában. A 2016 decemberében nyílt Amazon Go üzletek kamerák és szenzorok segítségével figyelik, hogy a fogyasztók milyen termékeket vesznek le a polcokról, vagy helyeznek vissza. A vásárlók az Amazon Go applikáció segítségével leolvassák a termékek vonalkódjait, amelyek a virtuális bevásárlókosárba kerülnek, majd az üzletből való távozáskor a vásárolt termékek értéke automatikusan levonódik a fogyasztó hitelkártyájáról (Wahba, 2018).

A digitalizáció előrehaladtával teret nyernek a mesterséges intelligencián alapuló, kiskereskedelmi megoldások, amelyek újfajta, ember-technológia kapcsolatokat hoznak létre.

Bár Bickmore és Picard (2005) kutatása szerint a technológia nem tudja az emberek közötti kapcsolat komplexitását, rugalmasságát leképezni, ezért csalódáshoz és 
frusztrációhoz vezetnek. Az újabb kutatások azonban kimutatták, hogy az ember-technológia kapcsolatban a fogyasztónak alacsonyabb az elvárása az együttmüködés, érzelmi és a kapcsolat intenzitása dimenziókban az ember-ember kapcsolatokhoz képest (Keeling et al., 2013).

Bolti környezetben a kiskereskedök leggyakrabban intelligens bevásárlókocsit, kiszolgáló robotokat, vagy virtuális promotereket használnak. Az intelligens bevásárlókocsi a vásárlót segíti az üzletben való navigálásban, a bevásárlólista alapján az egyes cikkelemek gyors megtalálásában, a termékinformációk és akciók keresésében, illetve kiegészítő termékek ajánlásában.

Robotok alkalmazásával a kiskereskedők a vásárlókról gyüjtött adatok alapján személyre szabott kiszolgálást tudnak biztosítani. Az amerikai Orchard Supply OSHboth elnevezésű robotokat foglalkoztat a barkácsáruházaiban. A robot üdvözli az üzletbe belépő vásárlót, majd készen áll arra, hogy a vásárlót informálja a keresett termékekről, illetve elvezesse a termékhez. Ezenkívül az a robot az eladószemélyzet számára is képes például az aktuális készletállományról információkat nyújtani (Dickenson, 2014).

További lehetőséget kínálnak a digitális technológia alkalmazására a virtuális eladók, amelyek elsősorban információnyújtásban, tanácsadásban segíthetik a kiskereskedelmi értékesítést. A virtuális eladó tulajdonképpen az eredeti eladó hologramként kivetített változata, aki képes a vevőkkel kommunikálni, információkat megosztani velük. Az eladószemélyzettel való kapcsolat szimulálására online kiskereskedelmi környezetben is van lehetőség. Egyre több vállalat alkalmaz olyan mesterséges intelligencián alapuló chatbotokat, amelyek képesek az emberekkel elöre meghatározott módon kommunikálni az online vásárlókkal (Olson, 2018). Az IKEA például tíz évig használta az Anna névre keresztelt virtuális asszisztenst vagy chatbot-ot, aki a honlapra látogató vásárlókat segítette információkkal (Rousselet, 2017).

\section{Termékek és szolgáltatások integrációja}

A kiskereskedelemben az áruválaszték és ebből fakadóan a termékek kiemelt szerepet játszanak, azonban a digitalizáció egyre inkább eltolja a hangsúlyt a termékalapú értékesítésről a szolgáltatásalapú értékesítés felé (Suarez et al., 2013). A termékek és szolgáltatások összefonódásának egyik megnyilvánulása, hogy egyes árucikkeket, amelyet korábban a kiskereskedők termék formájában értékesítettek (pl. film, zene), ma már túlnyomórészt digitális úton forgalmaznak (Hagberg et al., 2016). Teljes mértékben azonban nem lehet kiküszöbölni a kiskereskedelmi értékesítés materiális vonzatait, mivel a kiskereskedelmi szolgáltatások jelentős része fizikai termékekhez kötődik.

A termékek és szolgáltatások integrációjának az egyik leggyakrabban alkalmazott módja a személyre szabott ajánlatok és akciók biztosítása a vásárlók számára. A legnagyobb élelmiszer-kiskereskedelmi vállalatok a lojalitásprogramjaikat digitális platformra helyezték át, amely lehetőséget ad arra, hogy meghatározott termékekre személyre szabott akciókat, ajánlatokat kínáljanak a vásárlóik számára.

A szolgáltatásorientáció erőteljes megjelenését mutatja, hogy online környezetben kevesebb hangsúly van a konkrét áruválasztékon, inkább a problémamegoldás áll a középpontban. Jó példa erre a John Lewis angol kiskereskedelmi vállalat tulajdonában lévő Waitrose szupermarketlánc weboldala, ahol nem egyes árucikkek és akciók jelennek meg a kezdőlapon, hanem szezonális (tavaszi nagytakarítás, kertészkedés) vagy napi teendők (vacsorareceptek), ünnepek, illetve életmód (egészsé-

1. táblázat

A kiskereskedelmet átformáló digitális eszközök integrációs szerepe

\begin{tabular}{|c|c|c|}
\hline Integráció területei & Integráció jellemzői & Példák digitális eszközökre \\
\hline \multirow[t]{3}{*}{ Online és offline csatornák } & $\begin{array}{l}\text { bolti kiskereskedelem integrációja } \\
\text { online csatornával }\end{array}$ & $\begin{array}{l}\text { digitális kirakat, okostükör, interaktív } \\
\text { terminálok, intelligens bevásárlókocsi, RFID, } \\
\text { bluetooth, beacon }\end{array}$ \\
\hline & $\begin{array}{l}\text { online csatorna integrációja offline } \\
\text { csatornákkal }\end{array}$ & $\begin{array}{l}\text { click\&collect, click\&drive, dark store } \\
\text { virtuális szupermarketek közterületen }\end{array}$ \\
\hline & új közvetítők megjelenése & $\begin{array}{l}\text { többszereplős platformok } \\
\text { (ár- és termék-összehasonlítás), } \\
\text { fogyasztókat összekötő mobilapplikációk }\end{array}$ \\
\hline \multirow[t]{2}{*}{$\begin{array}{l}\text { Kiskereskedelmi és fogyasztói } \\
\text { szerepek }\end{array}$} & $\begin{array}{l}\text { a fogyasztó átveszi a kiskereskedő } \\
\text { feladatait }\end{array}$ & $\begin{array}{l}\text { önkiszolgáló technológiák } \\
\text { (pénztárgép, mobilszkennerek) }\end{array}$ \\
\hline & ember-technológia kapcsolatok & robotok, virtuális promoter, chatbot \\
\hline \multirow[t]{3}{*}{ Termékek és szolgáltatások } & személyre szabott ajánlatok & $\begin{array}{l}\text { lojalitásprogramok révén összegyüjtött } \\
\text { adatok alapján fejlesztett akciók } \\
\text { mobilapplikációk }\end{array}$ \\
\hline & problémamegoldás & $\begin{array}{l}\text { tematikus weboldalak } \\
\text { egészségügyi szolgáltatásokat nyújtó } \\
\text { mobilapplikációk }\end{array}$ \\
\hline & virtuális és kiterjesztett valóság & $\begin{array}{l}\text { termékek virtuális megjelenítése online és } \\
\text { offline térben }\end{array}$ \\
\hline
\end{tabular}


ges táplálkozás) köré rendezik az ajánlatokat (Morrell, 2007). Hasonló megoldások figyelhetők meg a vezető drogérialáncoknál. A Walgreens számos olyan egészségügyi szolgáltatást vezetett be, amely krónikus betegek ellátását segíti. A páciensek mobilapplikációk segítségével írathatnak fel receptet, amelyet szintén online továbbíthatnak a gyógyszertárnak. Ezenkívül sms-ben értékesítik őket, ha aktuális a következő adag gyógyszer felírása, kiváltása, továbbá számos egészségügyi, életvezetési tanácsot tartalmazó weboldalakat hoznak létre, vagy fontos szürővizsgálatok esedékességére hívják fel a figyelmet (Walgreens, 2010).

A kiskereskedelemben szintén megtalálhatók a virtuális valóságon alapuló szolgáltatások. Az IKEA virtuális lakberendező applikációja lehetővé teszi, hogy a tervezett új bútort az adott lakásrészben virtuálisan elhelyezzék, és ez alapján hozzák meg a vásárlási döntést. A nyomtatott katalógusban található, megjelölt termékeket beszkennelhetik a mobiltelefonjukkal. Majd az applikáció a kiválasztott terméket elhelyezi abban a térben, ahol a vásárló éppen tartózkodik. Így a felhasználók kipróbálhatják, hogyan is nézne ki pontosan a bútor a saját lakásukban (Morris, 2016).

A digitalizáció kiskereskedelmi tevekénységet integráló hatásait az 1. táblázat foglalja össze.

\section{Összegzés}

A cikk bemutatja, hogyan alakítják át és integrálják a digitális technológiák kiskereskedelmi tevékenység különböző területeit. Az elemzés során megvizsgáltam a kiskereskedelmi digitális technológiák integráló hatását az online és offline csatornákra, a kiskereskedelmi vállalat és a vásárlók kapcsolatára, illetve a termékek és szolgáltatások összefonódására vonatkozóan. A szakirodalom és a nemzetközi példák alapján a következő megállapításokat lehet megfogalmazni.

A digitalizáció által biztosított lehetőségek egyre jobban összefüzik a kiskereskedö által használt offline és online csatornákat. A fizikai üzlethálózat szerepe átalakul, illetve új disztribúciós formák és szereplők jelennek meg a vásárlási döntési folyamatban, amelyek sokszor a vásárlás egy-egy szakaszára (információkeresés, rendelés-feladás, áruátvétel) koncentrálnak. A kiskereskedő és fogyasztó közötti kapcsolat is megváltozik. A kiskereskedelmi vállalatok egyre több feladatot bíznak a fogyasztókra önkiszolgáló technológiák révén, valamint mesterséges intelligenciára épülő, digitális megoldásokkal (chatbot, robot, intelligens tükör, bevásárlókocsi) váltják ki az eladószemélyzet által végzett feladatok egy részét. Végül pedig az áruválasztékra koncentráló értékesítés helyett egyre inkább elötérbe kerülnek a szolgáltatások, amelyek problémamegoldásra és tanácsadásra helyezik a nagyobb hangsúlyt. Ezt a folyamatot nagymértékben támogatják az online, illetve a kiterjesztett, virtuális valóságra épülő digitális alkalmazások.

A digitalizáció kiskereskedelemre gyakorolt hatásainak bemutatása mellett, a kiskereskedelmi vállalatok számára is fontos következtetések fogalmazhatóak meg. Először is a kiskereskedők nem tekinthetnek az egyes digitális megoldásokra izolált eszközként, hanem a kiskereskedelmi tevékenység egészét támogató megoldásként kell a vásárlási döntési folyamatba integrálniuk az új technológiákat. Másodszor a vállalatoknak célszerü felismerniük, hogy a digitalizáció révén az értékesítési környezet kitágult, túllépett az online és fizikai üzlet határain. Ennek következtében nem csupán a vállalat által müködtetett csatornákat, hanem a vásárlási folyamat nem kereskedelmi színtereit is fontos figyelembe venni az értékesítési tevékenység tervezésénél. Harmadszor, a kiskereskedelmi vállalatoknak érdemes a vásárlók életmódja, illetve a számukra fontos események köré szervezni az ajánlatukat, amely jobban növeli a vásárlási élményt, mint a cikkelemekre és akciókra koncentráló választékpolitika. Ráadásul a tematikus választékbemutatás jelentős mértékben növeli a keresztértékesítési lehetőségeket. Végül pedig a digitális megoldások alkalmazásánál érdemes megfontolni, milyen módon lehet a fogyasztókat bevonni az értékesítési folyamatba, illetve a mesterséges intelligencián alapuló megoldások hogyan tudnak értéket teremteni a fogyasztó és a kiskereskedő számára.

Jelen cikknek nem volt célja, hogy empirikus kutatást végezzen a digitális technológiákkal kapcsolatban, hanem nemzetközi kiskereskedelmi vállalatok példáin mutatta be a digitalizáció átformáló, integráló hatását. Ennek következtében a cikk megállapításai korlátozottan általánosíthatók. A kutatás további folytatása során egyrészt konkrét kiskereskedelmi vállalatokra vonatkozóan esettanulmányok készítése a cél. Másrészt pedig a nemzetközi kiskereskedelmi cégek digitális innovációiban megmutatkozó szabályszerüségeket, valamint a digitális innovációk és vállalati teljesítmény kapcsolatát tervezem vizsgálni kvantitatív módszerekkel. A további elemzések alapjául egy nemzetközi kiskereskedelmi cégekböl álló paneladatbázis szolgál, amely vezetői kiskereskedelmi vállalatok innovációit tartalmazza a 2007-2017 időszakra.

\section{Felhasznált irodalom}

Anderson C. (2006): The Long Tail: Why the Future of Business Is Selling Less of More. New York: Hyperion Balaji, M.S. - Roy, S.K. (2017): Value co-creation with internet of things technology in the retail industry. Journal of Marketing Management, 33 (1-2), p. 7-31. https://doi.org/10.1080/0267257X.2016.1217914

Barone, M. - Roy, T. (2010): Does Exclusivity Always Pay Off? Exclusive Price Promotions and Consumer Response. Journal of Marketing, 74 (2), p. 121-132. https:// doi.org/10.1509/jmkg.74.2.121

Bearne, S. (2012): Tesco trials virtual shop at Gatwick. Marketing Week (Online Edition), 9. https://www.marketingweek.com/2012/08/07/tesco-trials-virtual-shopat-gatwick/. Letöltés dátuma: 2018. április 10.

Bickmore, T. - Picard, R. (2005): Establishing and maintaining long-term human-computer relationships. ACM Transportation, Computer -Human Interaction, 59(1), p. 21-30. http://www.ccs.neu.edu/home/bickmore/publications/toCHI.pdf. Letöltés dátuma. 2018. április 3.

Blitz, A. (2016): Beset by the digital revolution successful retailers embrace technology that enhances customer value. Strategy \& Leadership, Vol. 44, 6, p. 16-24. https://doi.org/10.1108/SL-09-2016-0073 
Blom, A. - Lange, F. - Hess Jr, R. L. (2017): Omnichannel-based promotions' effects on purchase behavior and brand image. Journal of Retailing and Consumer Services, 39, p. 286-295. https://doi.org/10.1016/j.jretconser.2017.08.008

Brynjolfsson, E. - Hu, Y.J. - Rahman, M.S. (2013): Competing in the age of omnichannel retailing. MIT Sloan Management Review, 54 (4), p. 23-29. https://search. proquest.com/docview/1399095562?accountid=15545

Cluley, R. - Brown, S. D. (2015): The dividualised consumer: sketching the new mask of the consumer. Journal of Marketing Management, 31(1-2), p. 107-122. https:// doi.org/10.1080/0267257X.2014.958518

Cullinane, S. (2009): From bricks to clicks: the impact of online retailing on transport and the environment. Transport Reviews, 29(6), p. 759-776. https://doi. org/10.1080/01441640902796364

Deloitte (2018): The Global Powers of Retailing 2018. https://www2.deloitte.com/global/en/pages/consumerbusiness/articles/global-powers-of-retailing.html. Letöltés dátuma: 2018. január 20.

Denegri-Knott, J. -Molesworth, M. (2010): Concepts and practices of digital virtual consumption. Consumption Markets \& Culture, 13 (2), p. 109-132. https://doi. org/10.1080/10253860903562130

Dickenson, S. (2014): Robots in retail: Meet OSHbot. Home Accents Today, 29(11), 20.

Doherty, N.F. - Ellis-Chadwick, F. (2010): Internet retailing: the past, the present and the future. International Journal of Retail and Distribution Management. 38 (11-12), p. 943-965. https://doi. org/10.1108/09590551011086000

Drug Store News (2015): Transforming the Retail Landscape. (2015). Drug Store News, 37(4), 41. Letöltés dátuma: 2018.04.10.

eMarketer. Worldwideretailand ecommercesales: eMarketer's estimates for 2016-2021. 18 July 2017. url: https:// www. emarketer.com/Report/Worldwide-Retail-EcommerceSaleseMarketers- Estimates-20162021/2002090, Letöltés dátuma: 2018. március 26.

Fors, A. C. (2010): The beauty of the beast: the matter of meaning in digitalization. AI \& society, 25(1), p. 27-33. https://doi.org/10.1007/s00146-009-0236-z

Fuentes, C. - Bäckström, K. - Svingstedt, A. (2017): Smartphones and the reconfiguration of retailscapes: Stores, shopping, and digitalization. Journal of Retailing and Consumer Services, 39, p. 270-278. https:// doi.org/10.1016/j.jretconser.2017.08.006

Gallagher, J. (2011): Stop \& Shop to Grow Scan It! in 2012. SN: Supermarket News, 59(44), 29

Gartner Research (2018): IT Glossary. https:/www.gartner.com/it-glossary/digitization. Letöltés dátuma: 2018. március 26.

Grewal, D. - Ailawadi, K. L.- Gauri, D. - Hall, K. - Kopalle, P. - Robertson, J. R. (2011): Innovations in retail pricing and promotions. Journal of Retailing, 87, p. 4352. https://doi.org/10.1016/j.jretai.2011.04.008

Grewal, D. - Roggeveen, A.L.- Nordfält, J. ( 2017): The future of retailing. Journal of Retailing, 93 (1), p. 1-6. https://doi.org/10.1016/j.jretai.2016.12.008
Groß, M. (2015): Mobile shopping: a classification framework and literature review. International Journal of Retail and Distribution Management, 43 (3), p. 221241. https://doi.org/10.1108/IJRDM-06-2013-0119

Hagberg, J. - Jonsson, A. - Egels-Zandén, N. (2017): Retail digitalization: Implications for physical stores. Journal of Retailing and Consumer Services, https://doi. org/10.1016/j.jretconser.2017.08.005

Hagberg, J. - Sundstrom, M. - Egels-Zandén, N. (2016): The digitalization of retailing: an exploratory framework. International Journal of Retail \& Distribution Management, 44 (7), p. 694-712. https://doi. org/10.1108/IJRDM-09-2015-0140

Hänninen, M. - Smedlund, A. - Mitronen, L. (2017): Digitalization in retailing: multi-sided platforms as drivers of industry transformation. Baltic Journal of Management, 2017 (4) https://doi.org/10.1108/BJM-04-2017-0109

Hernant, M. - Rosengren, S. (2017): Now what? Evaluating the sales effects of introducing an online store. Journal of Retailing and Consumer Services, 39, p. 305-313. https://doi.org/10.1016/j.jretconser.2017.08.010

Hultman, J. - Johansson, U. - Wispeler, A - Wolf, L. (2017): Exploring store format development and its influence on store image and store clientele - the case of IKEA's development of an inner-city store format. International Review of Retail, Distribution and Consumer Research, 27 (3), p. 227-240. https://doi.org/10.1080/0959 3969.2017.1314867

Huré, E. - Picot-Coupey, K. - Ackermann, C. L. (2017): Understanding omni-channel shopping value: A mixed-method study. Journal of Retailing and Consumer Services, 39, p. 314-330. https://doi.org/10.1016/j.jretconser.2017.08.011

Inman, J. J. - Nikolova, H. (2017): Shopper-Facing Retail Technology: A Retailer Adoption Decision Framework Incorporating Shopper Attitudes and Privacy Concerns. Journal of Retailing, 93(1), p. 7-28. https://doi. org/10.1016/j.jretai.2016.12.006

Internet Retailer (2012): ShopSavvy Gives Retailers Instant Access to Millions of Mobile Shoppers with ShopSavvy Marketplace. (online) Internet Retailer, Jun 4, 2012. https://www.digitalcommerce360.com/2012/06/04/ shopsavvy-gives-retailers-access-millions-mobileshoppers/. Letöltés dátuma: 2018.04.10.

Keeling, K. - Keeling, D. - McGoldrick, P. (2013): Retail relationships in a digital age. Journal of Business research, 66(7), p. 847-855. https://doi.org/10.1016/j. jbusres.2011.06.010

Lehdonvirta, V. (2013): A history of the digitalization of consumer culture. In: Digital virtual consumption. London: Routledge, p. 18-35.

McEleny, C. (2011): Sainsbury's ties in-store purchase to online interaction. (cover story). New Media Age, p. 1-3.

Meriam-Webster Online Dictionary: https://www.merriam-webster.com/dictionary/digitalization Letöltés dátuma. 2018. április 3

Moisander, J. - Eriksson, P. (2006): Corporate narratives of information society: Making up the 
mobile consumer subject. Consumption, Markets and Culture, 9(4), p. 257-275. https://doi. org/10.1080/10253860600921753

Morrell, S. (2007): Waitrose. New Media Age, 7/19/2007

Morris, C. (2016): Ikea Embraces Virtual Reality with Virtual Kitchen. Fortune.Com, 20. http:/fortune. com/2016/04/06/ikea-vr-virtual-kitchen/. Letöltés dátuma: 2018. április 10.

Olson, P. (2018): This AI Has Sparked A Budding Friendship With 2.5 Million People. Forbes.Com, https:// www.forbes.com/sites/parmyolson/2018/03/08/replikachatbot-google-machine-learning/\#7a8fe05d4ffa. Letöltés dátuma: 2018. április 10.

Pantano, E. - Timmermans, H. (2014): What is smart for retailing? Procedia Environmental Science, 22, p. 101-107. https://doi.org/10.1016/j.proenv.2014.11.010

Pantano, E. - Viassone, M. (2015): Engaging consumers on new integrated multichannel retail settings: challenges for retailers. Journal of Retailing and Consumer Services, 25, p. 106-114. https://doi.org/10.1016/j.jretconser.2015.04.003

Pantano, E. (2014): Innovation Drivers in Retail Industry. International Journal of Information Management 34, p. 344-350. https://doi.org/10.1016/j.ijinfomgt.2014.03.002

Pantano, E. - Priporas, C. (2016): The effect of mobile retailing on consumers purchasing experiences: a dynamic perspective. Computers in Human Behavior. 61, p. 548 555. https://doi.org/10.1016/j.chb.2016.03.071

Pauwels, K. - Leeflang, P.S.H. - Teerling, M.L. - Huizingh, K.R.E. (2011): Does online information drive offline revenues? Journal of Retailing, 87 (1), p. 1-17. https://doi. $\operatorname{org} / 10.1016 /$ j.jretai.2010.10.001

Renko, S. - Druzijanic, M. (2014): Perceived usefulness of innovative technology in retailing: consumers' and retailers' point of view. Journal of Retailing and Consumer Services, 21 (5), p. 836-843. http://dx.doi.org/10.1016/j. jretconser.2014.02.015.

Retail Design Blog (2012): Nike+ Fuelstation by Nike, London Boxpark. http://retaildesignblog.net/2012/03/12/ nike-fuelstation-by-nike-london-boxpark/ Letöltés időpontja: 2018. április 5.

Ritzer, G. - Jurgenson, N. (2010): Production, Consumption, Prosumption: The nature of capitalism in the age of the digital 'prosumer'. Journal of Consumer Culture, 10(1), p. 13-36. https://doi.org/10.1177/1469540509354673

Rousselet, V. (2017): The rise of the machines. Market Leader, (Q2), p. 34-35. https://www.marketingsociety.com/ the-gym/rise-artificial-intelligence-marketing. Letöltés dátuma: 2018.április 10.

Sainsbury's (2016): Sainsbury's set to launch Click \&Collect Groceries. Elérhető: http://www.jsainsbury.co.uk/media/ lateststories/2014/0606sainsburyssettolaunchclickcollec tgroceries/, Letöltés dátuma: 2018. április 10.

Savitz, E. - Koester, E. (2012): How The Web 'Check In' Is Growing Up. Forbes.com, 17.

Shankar, V. - Inman, J. J. - Mantrala, M. - Kelley, E. - Rizley, $R$. (2011): Innovations in shopper marketing: current insights and future research issues. Journal of Retailing, 87, p. 29-42. https://doi.org/10.1016/j.jretai.2011.04.007
Simpson, J. - Ohri, L. - Lobaugh, K.M. (2016): The New Digital Divide. Deloitte University Press (September 12, 2016). url: www2.deloitte.com/insights/us/en /industry/ retail-distribution/digital-divide-changing-consumerbehavior.html, Letöltés dátuma: 2018. március 26.

Sorescu, A. - Frambach, R.T. - Singh, J. - Rangaswamy, A. - Bridges, C. (2011): Innovations in retail business models. Journal of Retailing, 87, p. 3-16. ttp://dx.doi. org/10.1016/j.jretai.2011.04.005.

Ström, R. - Vendel, M. - Bredican, J. (2014): Mobile marketing: a literature review on its value for consumers and retailers Journal of Retailing and Consumer Services, 21 (6), p. 1001-1012. https://doi.org/10.1016/j.jretconser.2013.12.003

Suarez, F. F. - Cusumano, M. A. - Kahl, S. J. (2013): Services and the business models of product firms: an empirical analysis of the software industry. Management Science, 59(2), p. 420-435. https://doi.org/10.1287/mnsc.1120.1634

Taylor, E. (2016): Mobile payment technologies in retail: a review of potential benefits and risks. International Journal of Retail \& Distribution Management, 44(2), p. 159177. https://doi.org/10.1108/IJRDM-05-2015-0065

Tesco (2012): Annual Report and Financial Statement 2012. Elérhető: https://www.tescoplc.com/investors/reportsresults-and-presentations/reports-archive/ Letöltés ideje: 2017.08.13.

Verhoef, P. C. - Kannan, P. K. - Inman, J. J. (2015): From multi-channel retailing to omni-channel retailing: introduction to the special issue on multi-channel retailing. Journal of Retailing, 91(2), p. 174-181. https://doi. org/10.1016/j.jretai.2015.02.005

Verhoef, P. C. - Neslin, S. A. - Vroomen, B. (2007): Multichannel customer management: understanding the research-shopper phenomenon. International Journal of Research in Marketing, 24 (2), p. 129-148. https://doi. org/10.1016/j.ijresmar.2006.11.002

Wahba, P. (2018): Amazon Dishes About Its First Amazon Go Cashier-Free Store. Fortune.Com, 5. https://finance. yahoo.com/news/amazon-dishes-first-amazon-cashier-203008830.html. Letöltés dátuma: 2018. április 10.

Waitrose (2014): Waitrose's market leading Click \& Collect trial begins. (online) http://waitrose.pressarea.com/ pressrelease/details/78/NEWS_13/449, Letöltés dátuma: 2018. április 10.

Walgreens (2010): Annual Report 2010. (online) http://investor.walgreensbootsalliance.com/annuals-proxies. $\mathrm{cfm} ? \mathrm{c}=$ wag\&arArchive $=$ Archive. Letöltés dátuma: 2018. április 10.

Willems, K. - Smolders, A. - Brengman, M. - Luyten, K. Schöning, J. (2017): The path-to-purchase is paved with digital opportunities: An inventory of shopper-oriented retail technologies. Technological Forecasting and Social Change, 124, p. 228-242. https://doi.org/10.1016/j.techfore.2016.10.066

Zhou, W. - Duan, W. (2015): An empirical study of how third-party websites influence the feedback mechanism between online word-of-mouth and retail sales. Decision Support Systems, 76, p. 14-23. https://doi.org/10.1016/j. dss.2015.03.0100 